\section{Re-opening the case for natural theology}

\author{
Stanley L. Jaki
}

Creation and the World of Science: The Bampton Lectures, 1978. By A. R. Peacocke. (Clarendon/Oxford University Press: Oxford, 1979.) $£ 10$.

A THAW has been developing for the past decade or so in the icy truce between science and Christian religion. Such is the first thesis of the Reverend $\operatorname{Dr} \mathrm{A}$. R. Peacocke, Dean of Clare College, Cambridge, in this book, the greatly expanded form of the Bampton Lectures for 1978. Of course, there were some telltale events well antedating the 1970 s. It was a quarter of a century ago that Julian Huxley chose to drop from the second edition of his Religion without Revelation a crusading preface, his clarion call to all men to rid themselves, once and for all, of the illusion of being dependent on a personal God. Such a call is almost invariably orchestrated in that major key which is the presumed irreconcilability of science and religion and which is aimed primarily at the Christian creed, the major form of belief in God in the Western world, the cradle and powerhouse of science.

As to the past decade, it has widely witnessed the survival value of religion without revelation, after the late Jacob Bronowski refused to heed a suggestion of BBC Television to let them produce his Ascent of Man without its anti-Christian innuendos. Religion without revelation could, if the second Bronowski-lecturer (Philip Morrison) was right, be developed by termites, who, given enough time, perhaps billions of years, would come up, so he claimed, with a telescope worthy of Palomar. Like-minded pundits are no longer the exclusive voice of the world of science. Indeed, not since the days of a 'holy wedlock' between science and Christian religion (the days of Boyle and Newton) has it been as fashionable for scientists to refer to creation as is the case nowadays. Peacocke avoids following them into taking the $2.7^{\circ} \mathrm{K}$ cosmic background radiation for a measuring device of time elapsed since the moment of creation. At any rate, cosmology (the basic science, if all science is cosmology - a proposition endorsed by Popper and with no touch of falsifiability) is not among the major sources, surveyed by Peacocke, of the thaw in question. He rather emphasizes the rising awareness among scientists of the revisability and socio-psychological conditioning of their assumptions and theories. Another major source is that ecological concern which forced the scientific community to face up to questions of ethics, often germane to a theological perspective.

Therefore the times are propitious, Peacocke argues, for re-opening the case for natural theology. Indeed, its thorough recasting is in order, if it is true, and Peacocke, a biochemist by first training, has no doubt that science has clarified all basic questions about all forms of life, including man, by showing that all are but "living matter", so many complex agglomerates of atoms and molecules. Thus, if for the Christian theologian the world is to remain a "launching pad" towards its Creator, the world must be perceived through lenses "ground and polished by science" (page 48).

Peacocke does not have in mind a stance of "genuflecting to science", a stance anyhow incompatible with the stipulations of the Reverend John Bampton, Canon of Salisbury. The Bampton-lecturer, a scholar in Anglican orders, must preach "eight Divinity Lecture Sermons" on any of six specified topics, all of which restrict genuflection before the Triune God alone. Since the last of those topics, "the Articles of the Christian Faith, as Comprehended in the Apostles' and Nicene Creed", rests on the dogma of the createdness of all things visible and invisible, a thorough confrontation of science and Christian faith is unavoidable, if the latter is to remain a "reasoned service", a stipulation of the Apostle Paul. Such a confrontation is meaningful only if the merits of the respective claims of science and of (Christian) religion are subjected to a thorough scrutiny, which touches not only on the very foundations of Christian theology but also on those of science. Therefore an undertaking of this sort must be of considerable interest to those naturalscientist readers of Nature who cherish vistas of science extending far beyond their often extremely circumscribed specializations.

The theme of thaw and its background, which is the topic of Chapter 1 , is followed by "Cosmos, Man and Creation" in which the shift from the world picture of classical physics to that of modern physics, the interplay of chance and necessity, and the Judeo-Christian doctrine of creation are dealt with. Chance is again considered in Chapter 3, and with special attention to the ideas of Monod, Prigogine and Eigen on emergent systems. Peacocke's discussion of the mind-body relationship, the substance of Chapter 4, may have come more logically after his discussion of evolution ("The Selfish Gene and What Men Live By"'). All these chapters certainly should keep alive the interest of scientists.

Chapter 5, in itself a small book, is strongly theological, which is not to say that it is uninteresting. Peacocke's treatment of man's ethical nature and of Jesus' life and resurrection will delight those who savour process theology taken in a broader sense. Peacocke explicitly dissociates himself from neo-Thomists and Barthians. His predilection is rather with process theologians who showed marked interest in science and who published mostly during the past decade. While attention to the latest is certainly a great merit, it may also trap one in what Duhem memorably described as the "gossip of the moment", hardly ever the harbinger of depth. Is it really a sign of profundity to give, as Peacocke does, so much and sympathetic attention to a recent interpretation of "Yahweh" as meaning "He who makes things happen" and ignore at the same time its long-standing interpretation as Existence Itself, an interpretation that played a crucial role in the history of Western thought? At any rate, if the provenance of "Yahweh" must be sought in the political experience of the people, the question arises as to why other Semitic tribes, equally battered, failed to formulate it? Peacocke does not face up to this question, nor does he take a recourse to revelation, which incidentally, is mentioned only once throughout the book. A curious feature, because the last two chapters, on ecology and hope, respectively, are pivoted on the uniqueness of Jesus which Peacocke portrays over half a dozen, not too impressive pages, and because it is his stated view that in his lectures "there are involved ... a sequence of theological themes ... that echo credal phrases from the Book of Common Prayer" (page ix).

Those phrases, from creation through redemption to final consummation, take on, as articulated by Peacocke, a distinctly phenomenological ring. This is not to suggest even the slightest doubt about his deep commitment to the Creed. But no doubts could be raised on that score about Henry Longueville Mansel, author of The Limits of Religious Thought, the Bampton Lectures for 1858. Yet, an Oxford don, apparently of some stature, was heard to remark: "I had not expected to live to hear atheism preached from the pulpit of the University" (see V. F. Storr, The Development of English Theology in the Nineteenth Century 1800-1860; Longmans, Green: London, 1913; page 422). Not that Mansel would have wanted to give the slightest comfort to atheists, or to anticipate a religion without revelation. But as that perceptive don realized - and long before the inner logic of Mansel's highly applauded lectures dawned on all the premises on which he built could not accommodate a reasoned account of Christian revelation. Classic illustrations of the inexorable force of that logic can be gathered not only from theology and philosophy, but also from the sciences. The road is straight from Descartes to De la Mettrie, from Luther to Schleiermacher, from the early Copenhagen school to the multiworld-theory and the Tao of physics.

An ominous-looking logic may raise its head out of Peacocke's position on the 
mind-brain relationship, an inevitable consequence of his unqualified endorsement of the philosophy of emergent systems based on the work of Prigogine and others. To throw a strong light on this possibility, it may not be amiss to recall a remark which Herbert Feigl, the chief modern articulator of the identity theory of the mind-body relationship, made to the author of a book in which the case for dualism is unabashedly argued throughout: "Of course, I could not disagree more with you. Unfortunately I cannot do even that when reading some professedly Christian theologians on mind and body. I am unable to comprehend their contention that their position is different from mine". Needless to say, Feigl's position is compatible only with a religion without revelation as meant by Huxley. As to dualism, which Peacocke considers only in the perspectives of demonology and witchcraft, it is, in his eyes, an invitation to physicalist reductionism. This is certainly true of that parody of dualism produced by Descartes, a point not specified by Peacocke, who fails to mention even passingly other formulations of dualism. He opts for the identity theory, which he introduces with appreciative words on materialism and monism. His sole effort to retain the mind (soul) is a brief reference to the conceptual irreducibility of mental experiences to empirical parameters.

This is hardly enough, as would be noted by those taking a.long look both in Pusey Street and South Parks Road, respective symbols, in Peacocke's phrasing, of theological and scientific strongholds. They would point out that to discourse on an issue so crucial both to revealed religion and to religion without revelation as is the true nature of the mind-brain relationship, it is not enough "to note from the stands certain aspects of the state of the play". Peacocke states in the same breath: "I would not presume to enter the lists of that fearsome tillyard from which so many, more competent and distinguished philosophically than I am, have retreated to lick their logical wounds" (page 128). Wounds cannot be escaped as long as one truly joins the battle for truth. At most they can be kept disinfected by making one's position clear and thoroughly considered.

The absence of these two qualities undercuts time and again Peacocke's efforts. A subject like creation and the world of science brings one into encounter at every turn with that philosophy which cannot be done justice with the evasive remark that the case for a qualified realism, adopted in these lectures, "cannot be presented here" (page 22). This transparent tactic is in sight again after a long section on time as perceived in science (evolution) and in theology (eschatology): "The philosophical discussion of time is beyond our present scope" (page 334). Even natural-scientist readers, not overly sensitive to philosophical rigour, may feel uneasy on finding Peacocke declare in the next-to-last chapter that he had until then used the word nature "without any attempt to define it". After all, he himself tells his readers that several decades ago two scholars listed no less than sixty-six meanings of "nature", a number that could since then only increase.

A perhaps trivial, but telling sign that Nature is not static. Of this, Peacocke's book is a spirited and well-informed reminder. But in order to mean anything, Nature, and certainly man's nature, must retain some identity across the welter of change, especially if change is a true growth. Had Peacocke considered this basic philosophical issue, the touchstone of the truth of realism, with the seriousness it demands, his never-dull effort to portray the dynamism of world and man as "beingin-God" would have secured more persuasiveness for pan-en-theism, the label by which he wants his message to be known. The proofs of his book may have been read with unusual speed, though, undoubtedly, not with an eye on Canon Bampton's final stipulation: "the Preacher shall not be paid, nor be entitled to the revenue, before his sermons are printed."

Stanley L. Jaki is Distinguished University Professor at Seton Hall University, South Orange, New Jersey, and served as Gifford Lecturer at the University of Edinburgh 11975 and 1976) and Fremantle Lecturer at Balliol College, Oxford (1977).

\section{Lives of the stars}

The Uranium People. By L.M. Libby. Pp. 384. (Crane, Russak/Scribner's: New York, 1979.)\$15.95. To be published in the UK in May 1980 by Adam Hilger, at $£ 8.50$.

IT is easier to convey what this book is not than what it is. It is not a novel though it would be better and less offensive if it were. It is not in the category of memoirs, for although there are personal recollections, there is also a liberal use of the personal accounts of others. The reader will find the distinction between these two sources very un-sharp and will slowly learn that the geographical chapter headings have more to do with the subject treated than the location of the author. It is not a historical work in spite of the impression conveyed by the inclusion of references. Even these are inconsistent

\section{J.H. Manley}

with a historical work. Some quotes are unreferenced; practically none to official papers and compilations are included. In addition one is aware throughout of the intrusion of the author's opinions and tastes in people and events rather than the balanced pro and con of the careful historian or the insightful analysis of the biographer. The fact that the book grew out of a series of lectures as a university visitor suggests that the material and style were meant to be entertaining to students. I believe they were. There are many anecdotes, some amusing, some instructive, some flat. The author's statement of her purpose is to "tell not only what was scientifically interesting about the uranium-plutonium project but what was human and interesting about the people involved"'. Let us therefore consider her treatment of people and events.

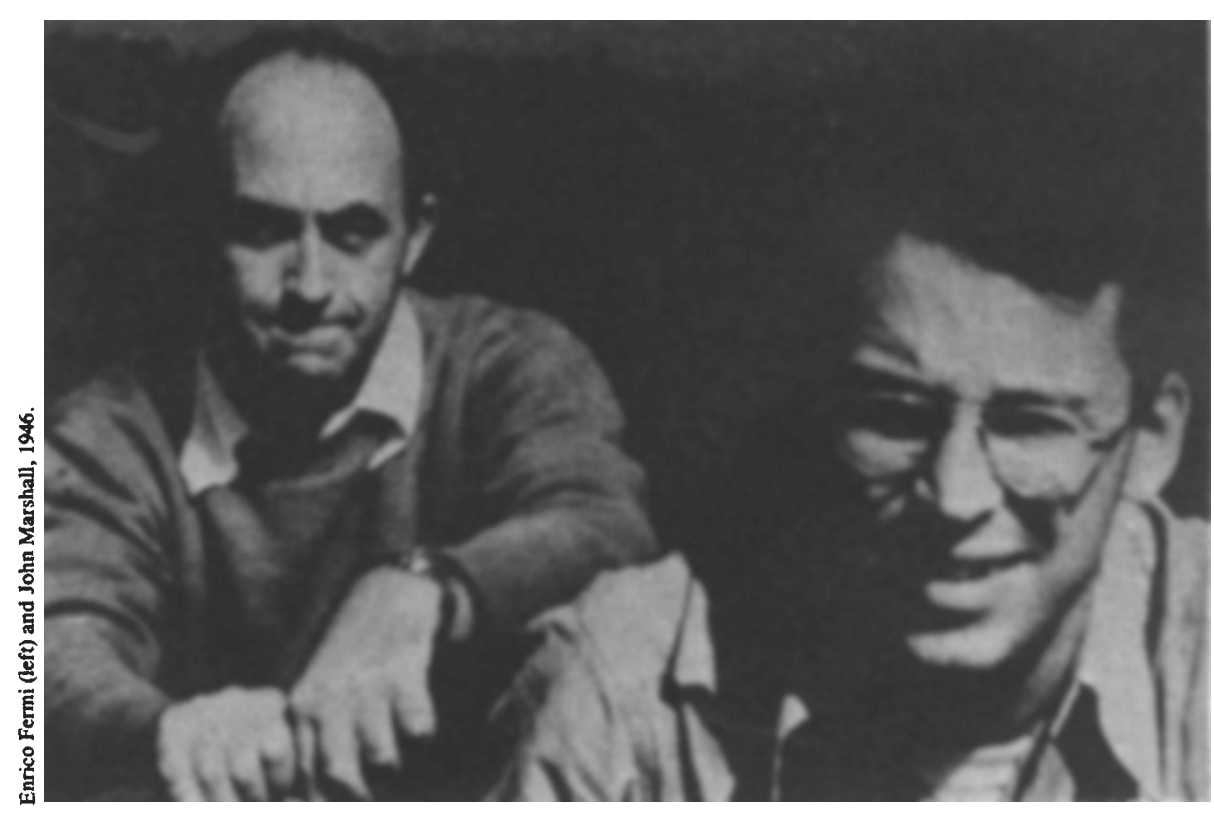

